not on concepts but on data, and rejects much of Ramey's evidence as being based on insufficient and poor quality data and contaminated samples. Ramey replies that his evidence does not hinge on those data points alone. After a slightly sharp series of exchanges on the Ramey work in the pages of Animal Conservation, experts seem to remain divided over the case. "If we look at the history of taxonomy, we often see that there have been many species named and then later synonymized," adds Dumbacher, who also sat on the Preble's mouse panel. "It may be that in the future, when the right studies are done, Preble's jumping mouse might be synonymized."

Criticisms of his data notwithstanding, Ramey says that his threshold is the right one, and that the level of difference between the Front Range mice and the rest is just too slight, in a world of limited resources, to justify any strenuous efforts to protect them. "We have to be willing to set priorities and stick to them. Right now, if you look at it, everything is a priority," he says.

Some suggest that the answer to all these problems is to ditch the taxonomic approach and shift to a totally different model of conservation law, such as ecosystem-based conservation. Many conservationists are thinking about

"We can all
agree on the
data, but
we can't all
agree on how
to apply the
names." - Jack
Dumbacher

concepts such as putting value on ecosystem services, such as water filtration and carbon sequestration. Mace sketches one possible ecosystem conservation model, in which several species' ranges are overlaid until a clear unit of space emerges. "You may have to deal with extreme specialists and those who like the edges of ecosystems separately," she adds. But when asked whether she thinks an approach like this will catch on in the near future, she sighs. "No," she says. "I think it is going to be very difficult because of the amount of expectation in policy-makers and legislators about the reality of the species concept. They really believe in it."

\section{Emma Marris is a correspondent for Nature in} Washington DC.

1. Barnes, P., Matheus, P., Shapiro, B., Jensen, D. \& Cooper, A. Science 295, 2267-2270 (2002)

2. Ramey, R. R., Liu, H.-P., Epps, C. W., Carpenter, L. M. \& Wehausen, J. D. Anim. Conserv. 8, 329-346 (2005)

3. Arbogast, B. S., Dumbacher.J. P. \& Steppan, S.J. Evaluation of Scientific Information Regarding Preble's Meadow-Jumping Mouse (Sustainable Ecosystems Institute, Portland, Oregon, 2006); available at http:// mountain-prairie.fws. gov/preble/Prebles_SEl report.pdf.

4. Isaac, N. et al. Trends Ecol. Evol. 19, 464-469 (2004).

5. Agapow, P. et al. Q. Rev. Biol. 79, 161-179 (2004).

6. Waples, R. S. Mar. Fish. Rev. 53, 11-22 (1991).

\title{
The big name hunters
}

\section{Professional taxonomists often bristle at non-professionals who name new species without going through peer review. But are amateur naturalists really bad for science? Brendan Borrell reports.}

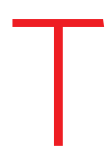

he death adders of Australia are not adders at all. Their closest relatives are cobras and coral snakes, but early naturalists were fooled by the snakes' stout body and triangular head. Even today, their taxonomy is a riddle: no one really knows where one species of death adder ends and the next begins.

In the late 1990s, only three species of death adder had been recognized, but herpetologists suspected that there were at least twice as many. Ken Aplin, then a curator at the Western Australian Museum in Perth, had spent years collecting data to back up that hunch. But before his study could be published, Raymond Hoser, a herpetologist not affiliated with an academic institution, described five new species of the snake in a 1998 issue of Monitor, a hobbyist magazine he edited for the Victorian Herpetological Society. Under the taxonomic code of the International Commission on Zoological Nomenclature (ICZN), Hoser's names — printed and disseminated to society members - take priority over any subsequent descriptions of the species. Aplin had been scooped ${ }^{1}$.

In the competitive world of taxonomy, countless amateurs have found success by collaborating with academics. Many professionals welcome their contributions; amateur enthusiasts are, in essence, a free workforce at a time when funding for basic taxonomy is waning. But cases such as Hoser's make some scientists wary of such contributions.

Hoser, who runs the snake-removal service Snakebusters in Melbourne, paints the picture as a classic case of academic élitism. "The description of me as an amateur is complete rubbish," he says. “There's no one in history who has spent so

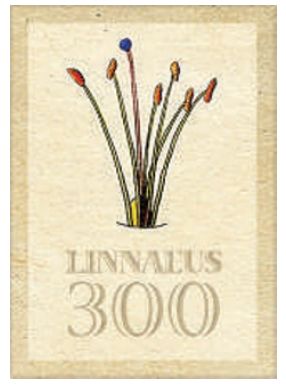

much time dealing with, looking at, catching and breeding death adders as myself." But his critics say it is not Hoser's credentials that they challenge. "A steady drip of shoddy descriptions" is how Wolfgang Wüster, an evolutionary biologist at the University of Wales in Bangor, describes Hoser's work. In a published critique, he and other leading herpetologists argue that Hoser "almost invariably fails to provide adequate information on his species, on their types, or on the material he has examined", making it difficult to repeat and test the observations ${ }^{2}$. Hoser, for his part, says that his descriptions contain more than adequate information.

\section{Seek, locate, describe}

But the ICZN, the group in charge of setting the ground rules for taxonomy, says it cannot police the quality of every published description. "It's a very tricky area to work in," says Andrew Polaszek, executive secretary for the organization. The commission, he says, will arbitrate only on pure nomenclature issues. In such a dispute, it will assess whether a Latin name put forward for a new species is valid under the taxonomic code. The code states that authors need to print the description of their species on paper, designate a type specimen, and list features that distinguish it from others. So just because a description is valid doesn't mean it is good. "The commission does not like to get involved in subjective taxonomy," Polaszek says.

Some taxonomists have proposed that the ICZN change its rules so that new species can be described only in peer-reviewed journals or through some other formal 
accreditation process. But others think that might impose too much of a burden on small society journals where many good descriptions are published without peer review. In short, no clear solution is forthcoming.

Centuries ago, amateur was the only way to be a naturalist. The linnaean nomenclature system arrived in England in 1760 and soon became "a parlour game for the leisure class", says retired historian David Allen in Winchester, UK. "People armed with guides to the flora took them out on their fashionable wanderings around the countryside." The surge in popular interest fuelled a rash of publications in club newsletters and self-financed monographs describing species and rearranging classifications. The backlash began almost immediately; even Charles Darwin criticized the vain "speciesmongers" who perpetuate a "vast amount of bad work" 3 . He thought the problem

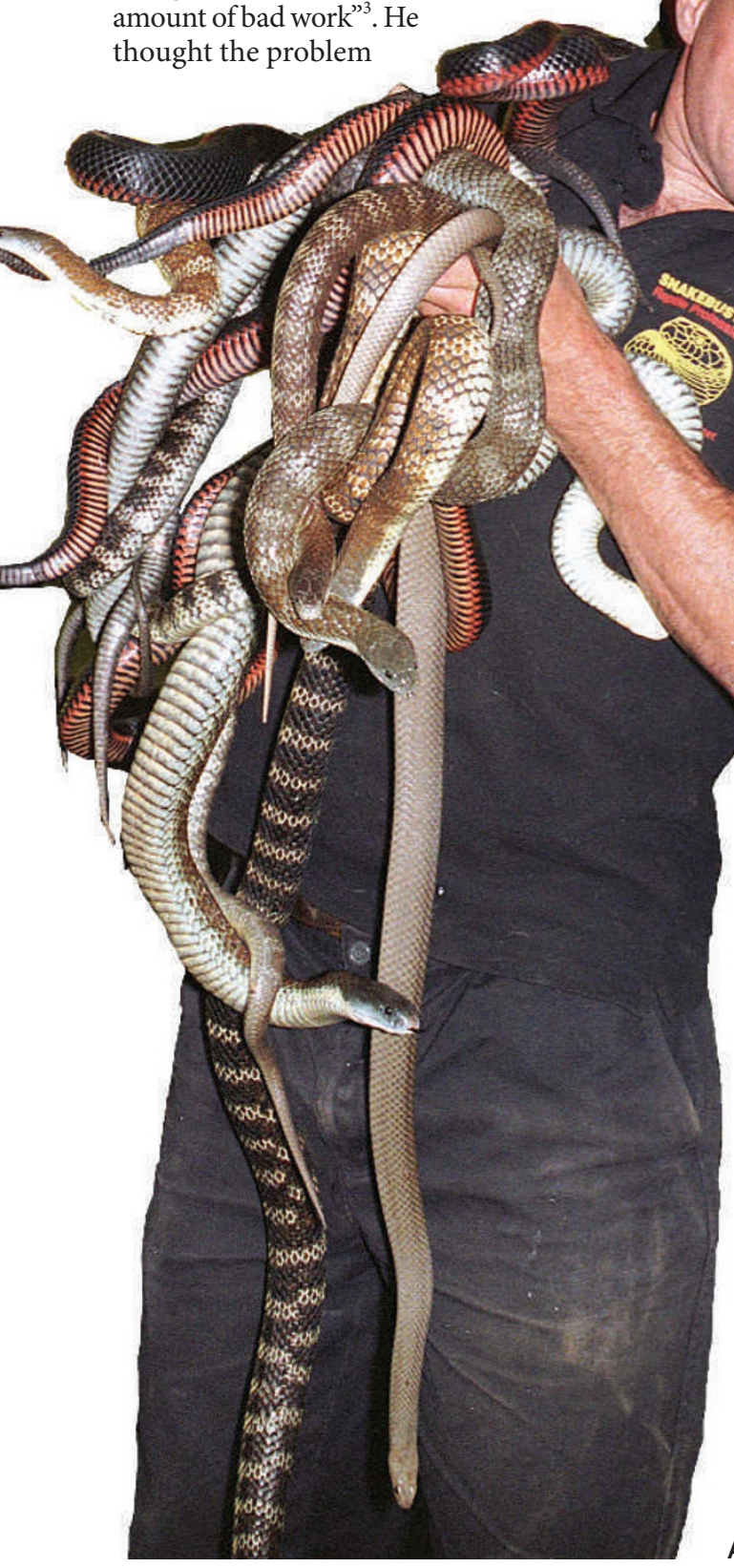

Snakes alive: Raymond Hoser has devoted years to studying Australian death adders. stemmed from this notion of priority, which he called "the greatest curse to natural history".

As a case in point, consider orchids. Two specialists recently published a plea against what they call "taxonomic exaggeration"4. As European botanists continue to subdivide orchid species that are not genetically distinct, they artificially inflate both the diversity and rarity of local flora, which may shift conservation priorities away from remote areas with fewer described species.

\section{A question of honour}

Orchids have long attracted a plethora of amateurs. In 2002, for instance, Michael Kovach smuggled a ladyslipper orchid from Peru and asked that a taxonomist at the Marie Selby Botanical Gardens in Sarasota, Florida, name it after him. Selby's experts reportedly knew that Eric Christenson, an unaffiliated taxonomist also in Florida, had his own description of the species scheduled for a forthcoming issue of Orchids. Selby rushed a two-page description of Phragmipedium kovachii to print as a supplement to its house journal. Kovach eventually pleaded guilty to illegal possession and trade of an endangered species; Selby was fined for its role in the scandal. None of this matters in the eyes of the taxonomic code, which will honour Kovach for ever.

Such 'orchid fever' has coloured the work of more than a few budding taxonomists. "There are lots of orchid amateurs who do not have a taxonomic background and who once in a while feel like they can make taxonomic changes," says Calaway Dodson, emeritus curator at the Missouri Botanical Garden. "Generally, it's a disaster." But some amateurs, he says, do excellent work. In Florida in the 1960s, a retired surgeon called Carlyle Leur began photographing the orchids of the state, and went on to document the entire country. Leur has since published more than 30 painstakingly illustrated monographs on the Pleurothallidinae, a daunting subfamily of orchids that contains more than 3,500 species.

Perhaps, then, the energy of amateurs can best be harnessed to fill the gaps in areas where few professionals work. The number of both professional and amateur taxonomists has been declining in Britain since the 1950s, according to a survey done in 2002 (ref. 5). But because they are distributed so widely, amateurs can generate better geographical coverage of flora and fauna, and focus on more descriptive taxonomy, leaving professionals free for molecular systematic studies.

\section{Ground force}

One successful venture, launched in 2002, is a partnership between government agency Natural England and the Natural History Museum in London, to encourage amateurs to contribute their data to local recorders. Museum experts have trained fly-fishermen to identify river flies and have enlisted members of the Ramblers' Association to monitor mature elm trees during their walks. The project met resistance from both sides at first, says sociologist Claire Waterton of Lancaster University. Some amateurs were reluctant to submit their data because they didn't understand how the work would be used, whereas others were worried that they would be judged unfavourably by professionals if they made mistakes. In turn, many professionals expressed concern about the quality of the data they might get. But in February, the British Mycological Society uploaded a database of fungal records to the 
National Biodiversity Network. Compiled by local groups in Britain and Ireland, the database contains 140,000 recorded samples dating back to the eighteenth century.

Technology is also an important way to harness amateurs' contributions. Charles Godfray, an evolutionary biologist at the University of Oxford, UK, has worked to set up a peerreviewed, single repository for all taxonomic information online - a sort of wiki-taxonomy ${ }^{6}$. That, he says, could help amateurs check the taxonomic designations of species that have been described. "The single thing that stops amateurs from being better involved in the process of taxonomy is getting at the literature," says Godfray. He is beginning to see his dream realized with a test website called CATE, for 'creating a taxonomic e-science, which he hopes will hold the taxonomy for aroids (popular house plants) and hawkmoths.

Polaszek notes that there is plenty of work for both amateurs and professionals. "We've got tens of millions of species to be described, and the easier this is, the better it is for everybody," he says. The ICZN is setting up a new system, called ZooBank, that requires species descriptions to be registered online. Within a year, he says, ZooBank could even be modified to include purely web publications such as CATE.

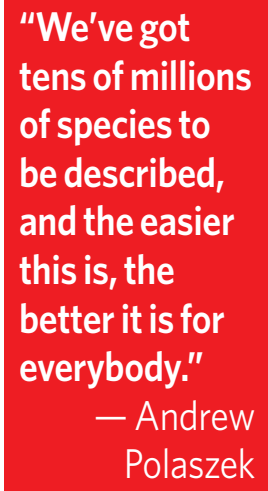

But could such changes sort out the mess over Australian reptiles? Perhaps not. In the 1980s, two amateur herpetologists called Richard Wells and Ross Wellington published more than 550 species descriptions that have since been changed $^{7}$. An attempt to annul the work of the pair was rebuffed by the ICZN and taxonomists still have to sort through this work to determine whether the names chosen by Wells and Wellington have priority over other publications.

Hoser, for his part, found inspiration in their example and christened one death adder Acanthophis wellsei. It may have been a fitting tribute, as the name itself was improperly constructed. In a redescription of the species, Aplin amended the name to Acanthophis wellsi.

Brendan Borrell is a freelance science writer in Arizona.
1. Aplin, K. P. Monitor 10, 104-109 (1999).

2. Wüster, W., Bush, B., Keogh, J. S., O'Shea, M. \& Shine, R. Litteratura Serpentium 21, 67-91 (2001).

3. Burkhardt, F. H. \& Smith, S. (eds) The Correspondence of Charles Darwin, Volume 4: 1847-1850, 210 (Cambridge Univ. Press, Cambridge, 1988).

4. Pillon, Y. \& Chase, M. W. Conserv. Biol. 21, 263-265 (2007)

5. Hopkins, G. W. \& Freckleton, R. P. Anim. Conserv. 5, 245-249 (2002)

6. Godfray, H. C. J. Nature 417, 17-19 (2002).

7. Thulborn, T. Nature 321, 13-14 (1986)

\section{The royal raccoon from Swedesboro}

\section{Although Linnaeus is best known for his botany and taxonomy, he was also an anatomist - and a keeper of pets. Henry Nicholls tells the story of Sjupp the raccoon.}

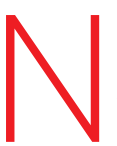

ot many people would respond to the death of a pet by dissecting it. But Carl Linnaeus was an exceptional man. In 1747, Sjupp, his pet raccoon, clambered over a fence at the botanical garden in Uppsala and met a dog on the other side. The meeting was not a happy one for the raccoon. Unwilling to forego the opportunity to describe the raccoon's anatomy and find out where it sat in his system of nature, Linnaeus laid the mauled body out on a slab and picked up his scalpel.

Linnaeus's subsequent account of his raccoon is a perfect illustration of his powers of observation and attention to detail. But it is also a record of tenderness and affection, steeped in the rhythms of daily life at the botanical gardens. It deals with the dead animal's character as well as its anatomy - and in so doing reveals something of the character of the anatomist himself.

Sjupp was a gift from crown prince Adolf Fredrik, known to Swedish schoolchildren as 'the king who ate himself to death' because he keeled over in 1771 after putting away 14 helpings of a traditional pudding. He was also, admittedly less memorably, a keen amateur naturalist as was his wife. The pair acquired thousands of natural-history specimens, according to Anthea Gentry, a research associate at the Natural History Museum in London who has been studying the mammals and birds in the Swedish royal collections.

"For the royal couple, this was an enterprise driven by a desire to establish a collection of the most rare, conspicuous and interesting species," says Gentry. The queen invited

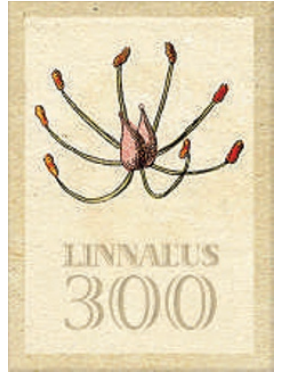

Linnaeus to catalogue and describe what they had acquired. Because they contain the specimens that Linnaeus used to describe various species - the 'type specimens' - the collections took on tremendous scientific significance. "They contain so many type specimens that they are as important as any other collection of similar size," says Gentry.

\section{Sweet tooth}

After Sjupp made the journey from the small zoo in the Royal Gardens in Stockholm to Uppsala he was kept in the royal manner to which he was accustomed. Although he would eat just about anything, "what he liked best were eggs, almonds, raisins, sugared cakes, sugar and fruit of every kind", Linnaeus observed ${ }^{1}$. "Should there be any cake or sugar on the table or in a cupboard he was on it in a flash, and thoroughly enjoyed himself. If a student came in who happened to have raisins or almonds on him, he at once attacked his pocket and fought until he had captured the spoil. On the other hand, he couldn't bear anything with vinegar on it, or sauerkraut, or raw or boiled fish."

Linnaeus went on from Sjupp's tastes to his temperament. "He became very friendly with people when he got to know them, letting them pat and play with him (especially if they ingratiated themselves by means of a few raisins)." But the raccoon also had a moody side. "Anyone who had once quarrelled with him found it almost impossible to get back again into his good books." Linnaeus's head gardener, who had once panicked and flapped when Sjupp bounded up to him and began to search his body for a tid-bit, suffered this disdain. 